\title{
DISCRETIONARY DEATH PENALTY FOR CONVICTED DRUG COURIERS IN SINGAPORE: REFLECTIONS ON THE HIGH COURT JURISPRUDENCE THUS FAR*
}

\author{
Chen Siyuan**
}

\begin{abstract}
For decades, drug trafficking was a serious offence in Singapore potentially punishable by mandatory death. In 2012, Singapore's Misuse of Drugs Act (MDA) was amended to give the courts sentencing discretion if the accused can first prove that he was merely a courier, and to better reflect the moral culpability accorded as between mules and kingpins in the hierarchy of drug syndicates. However, there are some complications in proving this. Not only must the accused show that he was merely a courier, he must also show that he had substantively assisted the authorities in disrupting drugtrafficking activities in Singapore. This raises an evidential quagmire as it is for the prosecution to certify that such assistance had indeed been rendered - the accused is therefore incentivised to admit to some form of guilt from the outset rather than to remain silent, since he may be precluded from adducing evidence of his role as a courier once the judge is satisfied that a drug-trafficking charge has been made out. Questions of self-incrimination and presumption of innocence are thus engaged. In addition, it is questionable if prosecutorial discretion should be further fortified by placing the certification power in the hands of the prosecutor. Finally, the MDA only states the preconditions of when there may be a discretionary death penalty, but does not state under what circumstances it should be preferred. Part 1 of this article establishes the background to Singapore's historical approach towards drug-trafficking. Part 2 provides a synopsis of the first major High Court decision that addressed the amended MDA provision, while Part 3 analyses the decision as well as related case law. Concluding observations reside in Part 4.
\end{abstract}

\footnotetext{
* An earlier version of this paper was presented at the International Conference on Law, Order, and Criminal Justice 2014, which in turn was based on my case comment in Chen Siyuan, "Singapore's New Discretionary Death Penalty for Drug Couriers: Public Prosecutor v Chum Tat Suan," International Journal of Evidence \& Proof 18(3) (2004):260. Comments from the conference audience have been gratefully adopted. I thank my Research Assistant Jason Lim (JD, SMU) for his help in updating the paper, though of course all errors remain mine.
}

** Assistant Professor of Law, Singapore Management University. 
Keywords: Misuse of Drugs Act, presumption of innocence, discretionary death penalty, drug courier, sentencing guidelines

\title{
BUDI BICARA HUKUMAN MATI TERHADAP PEMBAWA DADAH YANG DISABITKAN DI SINGAPURA: RENUNGAN TERHADAP PERUNDANGAN MAHKAMAH TINGGI SETAKAT INI
}

\begin{abstract}
ABSTRAK
Buat sekian lama, pengedaran dadah merupakan jenayah yang serius di Singapura dan ianya boleh dikenakan hukuman mati mandatori. Pada tahun 2012, Singapura telah meminda Akta Penyalahgunaan Dadah. Pindaan ini telah memberikan Mahkamah Tinggi kuasa untuk memilih hukuman yang wajar diberikan kepada pesalah yang hanya menjadi keldai dadah. Walaubagaimanapun, Kuasa Mahkamah Tinggi ini hanya boleh dilaksanakan jika tertuduh berjaya membuktikan pembabitannya dalam jenayah tersebut hanyalah sebagai pembawa dadah. Walaubagaimanapun beban pembuktian adalah agak tinggi dan sukar dipenuhi pihak tertuduh. Ini kerana dia juga terpaksa menunjukkan bahawa tertuduh juga turut membantu pihak berkuasa dalam usaha membenteras jenayah tersebut di Singapura. Ini membebankan tertuduh kerana sepatutnya beban pembuktian ini perlu dipenuhi oleh pihak pendakwaan bagi memenuhi kehendak pindaan ini, tertuduh seolah-olah digalakkan mengaku salah bagi membolehkannya mengguna pakai pengecualian tersebut. Tertuduh juga seolah-olah di nafikan hak untuk berdiam diri. Ini menimbulkan permasalahan tertuduh memburukkan diri sendiri dan ini menyalahi kaedah seorang itu dianggap tidak bersalah hingga terbukti demikian. Selain itu pindaan tersebut juga tidak memberi panduan jelas tentang keadaan yang membolehkan pihak Mahkamah membuat pilihan tersebut. Oleh itu, Bahagian 1 makalah ini akan membincangkan latar belakang terhadap pengedaran dadah di Singapura. Bahagian 2 pula memberikan sinopsis kepada keputusan Mahkamah Tinggi yang pertama setelah pindaan yang dilakukan terhadap Akta Penyalahgunaan Dadah 2012. Sementara itu Bahagian 3 pula melihat senarai kes-kes yang berkaitan. Bahagian 4 akhirnya merumuskan pengamatan yang telah diberikan.
\end{abstract}

Kata kunci: Akta Penyalahgunaan Dadah, kaedah seorang itu dianggap tidak bersalah hingga terbukti demikian, budi bicara hukuman mati, pembawa dadah, kaedah-kaedah menjatuhkan hukuman 


\section{BACKGROUND: THE CHANGE IN THE LAW FOR DRUG COURIERS}

The Singapore government has long adopted an uncompromising stance against drug trafficking in the laws it has enacted. Very severe punishments - ranging from caning and long-term imprisonment to the death penalty - have been justified by the government on communitarian policy grounds that drug addiction has the clear potential to upset the fabric of society, break up families, and cause addicts to turn towards a cycle of violent crime to feed their addiction. ${ }^{1}$ These punishments are coupled with a series of presumptions built into the Misuse of Drugs Act (MDA), ${ }^{2}$ designed to disrupt the efforts of drug syndicates from around the region - perhaps the worst hotbed for illegal drug activities in the world ${ }^{3}$ - from smuggling their merchandise into Singapore.

For example, pursuant to section 18 of the MDA, any person who is found with controlled drugs is presumed to have had those drugs in his possession and also presumed to have known the nature of those drugs. ${ }^{4}$ Further, under section 17, if the controlled drugs in question exceed a certain quantity, there is a presumption that it is for the purpose of trafficking. Currently, in order to successfully rebut these presumptions, the requisite standard of proof is on a balance of probabilities instead of having to prove it beyond reasonable doubt. Therefore, it makes it harder for the accused drug trafficker to secure an acquittal. The Singapore courts have long held that this is an entirely

\footnotetext{
See Second Reading of Misuse of Drugs (Amendment) Bill, Singapore Parliament Reports, 12 November 2012.

2 Misuse of Drugs Act (Chapter 185, Revised Edition 2008). The MDA finds equivalents to varying degrees in other jurisdictions such as Malaysia and Hong Kong (see Abdul Rani Kamarudin, "The Misuse of Drugs in Malaysia: Past and Present," Jurnal Antidadah Malaysia 1, no. 1 (June 2007): 9-19. This discussion of the new MDA provisions may thus be of interest to such jurisdictions. Singapore shares similar legislation on both criminal and evidence law with Malaysia as well.

3 "Strong Growth in Myanmar Boosts Opium Production in 'Golden Triangle' - UN Report, "United Nations, accessed December 1, 2014, http:// www.un.org/apps/news/story.asp? NewsID $=46773 \& \mathrm{Cr}=$ opium $\& \mathrm{Cr} 1=\#$. U970WWOupEI For instance, according to the United Nations, Myanmar - which is part of the Golden Triangle - is the second largest producer of opium in the world.

For a commentary on this, see Chen Siyuan and Nathaniel Khng, "Possession and Knowledge in the Misuse of Drugs Act," Singapore Law Review 30 (2012): 181.
} 
legitimate interest that Parliament can pursue. ${ }^{5}$ A successful conviction for drug trafficking could, depending on the quantity trafficked as set out in the charge, lead to the mandatory death penalty. ${ }^{6}$

Human rights and constitutional challenges have thus been mounted against the legality of the MDA (including its provisions on the mandatory death penalty) over the years, but none of them have ever succeeded before the Singapore courts. ${ }^{7}$ The Singapore government's position over the years has largely been consistent, in that the death penalty serves as the best deterrent against drug trafficking, which it considers to be one of the gravest and most serious crimes possible. ${ }^{8}$ In his 2014 speech at the $69^{\text {th }}$ Session of the United Nations General

Tan Kiam Peng v Public Prosecutor [2008] 1 SLR(R) 1, [54]-[61]; Nagaenthran a/l K Dharmalingam v Public Prosecutor [2011] 4 SLR 1156, [27]-[31]; Dinesh Pillai a/l K Raja Retnam v Public Prosecutor [2012] 2 SLR 903, [18]; Muhammad Ridzuan bin Md Ali v Public Prosecutor [2014] 3 SLR 721, [75]. In a sense, this is not anomalous, given that section 107 of the Evidence Act (Chapter 97, Revised Edition 1997) states that "When a person is accused of any offence, the burden of proving the existence of circumstances bringing the case ... within any special exception or proviso contained in ... any law defining the offence, is upon him, and the court shall presume the absence of such circumstances". Further, section 108 states that "When any fact is especially within the knowledge of any person, the burden of proving that fact is upon him." These provisions, however, have been claimed to contradict common notions of the right to a presumption of innocence and may even be unconstitutional under Singapore law: Michael Hor, "The Presumption of Innocence - A Constitutional Discourse for Singapore," Singapore Journal of Legal Studies (1995):369-371. See also Public Prosecutor v Kum Chee Cheong [1993] 3 SLR(R) 737, [39].

See MDA, sections 5, 7, 33, and Second Schedule.

See generally Chen Siyuan, "A Preliminary Survey of the Right to Presumption of Innocence in Singapore," LAWASIA Journal 7 (2012): 78; Chen Siyuan, "The Limits on Prosecutorial Discretion in Singapore: Past, Present, and Future," International Review of Law, no. 1 (2013): 1. Certain international organisations also make the sensationalist claim that Singapore has the highest rate of executions in the world, though it is true that an overwhelming percentage of drug trafficking prosecutions in Singapore do result in convictions. For a survey on the related discussion of whether there are wrongful convictions in Singapore, see Chen Siyuan and Eunice Chua, "Wrongful Convictions in Singapore: A General Survey of Risk Factors," Singapore Law Review 28 (2010):98, wherein the authors conclude that the rate of such convictions in Singapore is almost negligible. For a discussion on how a mandatory death penalty regime may be illegal under international law standards, see Michael Hor, "The Death Penalty in Singapore and International Law," Singapore Yearbook of International Law 8 (2004): 105.

8 The Singapore government considers drug trafficking to be so serious an offence that it occasionally resorts to the detention without trial of certain traffickers. One of the statutes that permit this is the Criminal Law (Temporary Provisions) Act (Chapter 67, Revised Edition 1985), which was originally enacted in 1955 and was expected to be repealed after stability in then crime-ridden Singapore was established. 
Assembly, Singapore's Minister for Foreign Affairs and Minister for Law reiterated that, "Drug traffickers impose immense penalties, including the death penalty, on their victims ... We want to protect our people from becoming victims, and to protect our society." The death penalty therefore looks likely to remain in Singapore's statute books for the foreseeable future.

Nonetheless, perhaps in a bid to "draw a very careful, calibrated distinction between the different levels of accountability," between kingpins and mules in drug syndicates, and to "temper and mitigate the harsh drug laws with compassion", the MDA was amended in $2012 .{ }^{10}$ One of the most significant changes was the introduction of section 33B, which gives any judge hearing a capital drug trafficking case the discretion to impose a sentence of life imprisonment ${ }^{11}$ and caning instead of the death penalty for low-level drug operatives if two

But even as late as 2013, the life of the provision was extended for the umpteenth time, complete with approval from the opposition party in Parliament: Second Reading of Criminal Law (Temporary Provisions) (Amendment) Bill, Singapore Parliament Reports, 11 November 2013. See also Second Reading of Corruption, Drug Trafficking and Other Serious Crimes (Confiscation of Benefits) (Amendment) Bill, Singapore Parliament Reports, 7 July 2014 for the latest parliamentary affirmation on the war on drugs.

9 Ministry of Foreign Affairs (Singapore), Transcript of Statement by Minister for Foreign Affairs and Minister for Law K Shanmugam at the High-Level Side Event at the $69^{\text {th }}$ Session of the United Nations General Assembly, "Moving Away from the Death Penalty: National Leadership", accessed December 1,2014, http://www.mfa.gov.sg/content/mfa/media_centre/press_room/pr/2014/201409/ press_201409261.html.

10 Second Reading of Misuse of Drugs (Amendment) Bill (Edwin Tong). One of the recurring criticisms by opponents to the mandatory death penalty is that more often than not, the traffickers arrested are "mules" who are usually in desperate need for money rather than the masterminds or kingpins of well-organised drug syndicates. The somewhat controversial Court of Appeal decisions in Nguyen Tuong Van v Public Prosecutor [2005] 1 SLR(R) 103 and Yong Vui Kong v Public Prosecutor [2010] 3 SLR 489 are often cited as examples by such detractors, though in the latter case, the accused's death sentence was eventually commuted to imprisonment and caning pursuant to the amended MDA.

For a commentary on the meaning of "life imprisonment", see Chen Siyuan, "The Meaning of 'Life Imprisonment' in the Context of a Presidential Commutation Order," Singapore Law Watch Commentaries 3 (2012). It should also be noted that this set of discretionary measures were simultaneously introduced with a similar set for murder offences under the Penal Code (Chapter 224, Revised Edition 2008). For an overview of both, see Mohammad Faizal and Wong Woon Kwong, "Changes to the Mandatory Death Penalty Regime - An Overview of the Changes and Some Preliminary Reflections," Singapore Law Gazette, (September 2013) http://www. lawgazette.com.sg/2013-09/842.htm, accessed December 1, 2014. 
conjunctive conditions are met. ${ }^{12}$

First, the accused must prove, on a balance of probabilities, that his role in the offence (of drug trafficking) was restricted to that of a courier within his drug syndicate $;^{13}$ and secondly, the prosecution must certify that the accused had substantively assisted the Central Narcotics Bureau (CNB) in disrupting drug trafficking activities within or outside Singapore. That is the gist of this new provision. There is no indication in the relevant records that the provision was inspired by any particular jurisdiction. The relevant parts of section 33B reads: ${ }^{14}$

33B. - (1) Where a person commits or attempts to commit [trafficking in controlled drugs and importing and exporting controlled drugs], being an offence punishable with death ... and he is convicted thereof, the court -

(a) may, if the person satisfies the requirements of subsection (2), instead of imposing the death penalty, sentence the person to imprisonment for life and, if the person is sentenced to life imprisonment, he shall also be sentenced to caning of not less than 15 strokes ...

12 Second Reading of Misuse of Drugs (Amendment) Bill (Teo Chee Hean). In Singapore, pursuant to section 9A of the Interpretation Act (Chapter 1, Revised Edition 2002), it is necessary to refer to parliamentary reports as a first port-of-call when interpreting statutory provisions. "In the interpretation of a provision of a written law, an interpretation that would promote the purpose or object underlying the written law (whether that purpose or object is expressly stated in the written law or not) shall be preferred to an interpretation that would not promote that purpose or object."

13 Second Reading of Misuse of Drugs (Amendment) Bill (Teo Chee Hean). "Courier" is not a term that is actually used in the MDA; instead, as can be seen, the key words used in section 33B are "transporting, sending or delivering" controlled drugs. It was also clarified in Parliament that the narrow scope of section 33B would not extend to accused persons who have packed or stored the drugs.

14 Alternatively, it is open to the accused (under subsection 3 which is not reproduced here) to prove, also on a balance of probabilities, that he was suffering from an abnormality of mind to the extent that it substantially impaired his mental responsibility for his acts and omissions in relation to the trafficking or import and export of controlled drugs. This is known as the defence of diminished responsibility, which under the Penal Code is a specific defence to culpable homicide. However, the discussion on diminished responsibility is rather distinct and falls outside the scope of the present endeavour. 
(2) The requirements referred to in subsection (1)(a)are as follows:

(a) the person convicted proves, on a balance of probabilities, that his involvement in the offence ... was restricted -

i. to transporting, sending or delivering a controlled drug;

ii. to offering to transport, send or deliver a controlled drug;

iii. to doing or offering to do any act preparatory to or for the purpose of his transporting, sending or delivering a controlled drug; or

iv. to any combination of activities in sub-paragraphs (i), (ii) and (iii); and

(b) the Public Prosecutor certifies to any court that, in his determination, the person has substantively assisted the Central Narcotics Bureau in disrupting drug trafficking activities within or outside Singapore.

$[\ldots]$

(4) The determination of whether or not any person has substantively assisted the Central Narcotics Bureau in disrupting drug trafficking activities shall be at the sole discretion of the Public Prosecutor and no action or proceeding shall lie against the Public Prosecutor in relation to any such determination unless it is proved to the court that the determination was done in bad faith or with malice.

Before the 2012 amendments to the MDA, an accused facing a drug trafficking charge was already in an unenviable position in terms of how likely he is able to successfully prove his innocence. But did the amendments make matters even more difficult, despite initial perceptions 
that the amendment was meant to be more compassionate? ${ }^{15}$ The High Court in Public Prosecutor v Chum Tat Suan (Chum Tat Suan (High Court) $)^{16}$ certainly thought so, but nevertheless proceeded to conclude that the accused person was indeed a courier for the purpose of section 33B.

Proceedings, however, came to a standstill as the AttorneyGeneral's Chambers immediately filed a Criminal Reference ${ }^{17}$ to the Court of Appeal (the apex court in Singapore), seeking clarification and guidance on some of the comments made by the judge in Chum Tat Suan (High Court). There was thus a stay on the sentence pending the Court of Appeal's decision. Unfortunately, at the completion of this article, the Court of Appeal had yet to render its decision. This article will thus focus on the High Court decision (which was the first major decision to comment on the amended provisions of the MDA) as well as related case law from the same court. Specifically, the focus will be on some of the main evidential and sentencing issues that arise.

15 See for instance Hor, "The Death Penalty in Singapore and International Law". To be clear, the discretionary death penalty is not entirely new to Singapore's criminal justice system. Kidnapping, for instance, is an offence that can either result in life imprisonment and caning or the death penalty: Chandra Mohan and Priscilla Chia, "The Death Penalty and the Desirability of Judicial Discretion," Singapore Law Gazette (March 2013), accessed December 1, 2014http:/www.lawgazette.com. sg/2013-03/697.htm.

16 Public Prosecutor v Chum Tat Suan [2014] 1 SLR 336 (High Court). The High Court is the second-highest court in Singapore, after the Court of Appeal. It should be noted that the judge who heard this case also heard Public Prosecutor v Abdul Kahar bin Othman [2013] SGHC 222, which also dealt in part with the same issues (the details of which need not detain us). The two judgments were released on the same day. Notably, Chum Tat Suan (High Court) was only the second case to have considered and applied section 33B of the MDA. The first was Public Prosecutor v Abdul Haleem bin Abdul Karim [2013] 3 SLR 734, where the court made certain important observations as to how the role of a drug courier should be interpreted under section 33B. One of the appeals that arose from the decision has since been decided (see Muhammad Ridzuan bin Md Ali), but this appeal did not concern issues relating to section 33B.

17 This was probably done pursuant to Supreme Court of Judicature Act (Chapter 322, Revised Edition 2014), section 59. A Criminal Reference ought to be distinguished from a Criminal Motion. In the former, questions of law that are of public interest are presented to the Court of Appeal - for instance where the High Court has already exercised its appellate jurisdiction and there is no further right to appeal to the Court of Appeal. Whether or not leave is granted for a Criminal Reference to be filed will be considered in a Criminal Motion, though other types of orders may also be sought in a Criminal Motion, such as extensions of time or adductions of further evidence. For a representative case, see James Raj s/o Arokiasamy v Public Prosecutor [2014] SGCA 33. 


\section{DECISION IN CHUM TAT SUAN (HIGH COURT)}

The key facts of the case was in relation to the accused, now almost 70 years old, ${ }^{18}$ who was charged with importing 94.96 grams of diamorphine into Singapore some time in 2010. This amount was considerably higher than the 15 gram threshold that triggered a potential death penalty sentence. ${ }^{19}$ His main defence was that the bag (which contained the drugs) found in the boot of the taxi he was in was not his. He also insisted that in any case, he did not know what was in the bag.

Justice Choo Han Teck did not believe this defence and convicted him, and consequently section 33B of the MDA was engaged. As this was a new area of the law, Justice Choo sought further submissions for a separate hearing on sentencing, and the parties returned with a jointly agreed proposal. ${ }^{20}$ According to that proposal, the judge must first determine the preliminary question of whether the accused was indeed a courier; if the answer was no, then the mandatory death penalty ensues. If the answer was yes, the prosecution would - presumably after seeking an adjournment of the hearing - record a statement from the accused so that it can decide whether to certify that the accused had substantively assisted CNB in disrupting drug trafficking activities within or outside Singapore. If the prosecution so certifies, the judge would then decide if the death penalty or life imprisonment and caning is the more appropriate punishment. ${ }^{21}$

Justice Choo, however, described this multi-step proposal as giving rise to a "significant difficulty". ${ }^{22} \mathrm{He}$ elaborated on his position in the following terms:

I have already convicted the accused on the basis of findings of fact that I have made. But now I have to make new findings on at least one

\footnotetext{
18 See Public Prosecutor v Chum Tat Suan [2013] SGHC 150. Singapore law only prohibits the death penalty being passed on persons below 18 years (at the time the offence was committed) and pregnant women: Criminal Procedure Code (CPC) (Chapter 68, Revised Edition 2012), sections 314 and 315.

19 See MDA, Second Schedule read with section 33B.

20 Chum Tat Suan (High Court), [4].

21 An additional step was actually proposed: if the prosecution declines to certify, both parties would make submissions on whether the accused nonetheless was suffering from an abnormality of mind at the material time, assuming that such a defence was raised. In this regard the Court of Appeal had recently pronounced that the trial judge has a duty to consider alternative defences that might reasonably be made out: Public Prosecutor v Mas Swan bin Adnan [2012] 3 SLR 527, [63]-[80].

22 Chum Tat Suan (High Court), [5].
} 
question of fact for the purposes of sentencing, which is whether the accused was no more than a "courier". If I allow parties to introduce new evidence ... there is the possibility of evidence emerging that might undermine the findings of facts that I had earlier made in convicting the accused. There is even the possibility of evidence emerging that casts doubt on the guilt of the accused. On the other hand, if I do not allow the introduction of any new evidence, and premise my decision on sentencing exclusively on the findings of fact that I have already made and the evidence that had been adduced at trial, there is a possibility of prejudice to the accused, in that he might have conducted his defence in such a manner as to furnish no occasion for evidence of his being no more than a "courier" to emerge at trial. This would make it difficult or impossible for him now to prove, without introducing further evidence on the question, that he was no more than a "courier". I think this difficulty is not confined to the present case but is one which may afflict all cases in which the accused faces a capital charge under the MDA. ${ }^{23}$

Justice Choo further noted that the alternative approaches to either decide issues of conviction and sentence together or to have the sentencing submissions based only on the evidence adduced at trial would only serve to put the accused "in a bind":

[I]n order to make the claim that he was no more than a "courier", the accused must first admit that he was trafficking or importing or exporting drugs. Choosing not to admit this might subsequently preclude him from arguing that he was no more than a "courier" should the court convict him nonetheless. For instance, if the accused elects to remain silent because he is of the opinion that the prosecution has not made out a case against him, and the court convicts him anyway, he would not have had the opportunity to give evidence for the purposes of proving that he was no more than a "courier". If his case was that he did not know that he had drugs in his possession, or that he had them in his possession for his own personal consumption, the evidence he gives and adduces at trial would be directed towards proving that case rather than that he was no more than a "courier". Consequently, should the court disbelieve his defence and convict him, it would be difficult or impossible for him to argue that he was no more than a "courier". One response might be that the accused must take a position and stick with it. But the onus is not on the accused to take positions. Since the Prosecution seeks to invoke the court's authority to punish the accused, the onus is on the Prosecution to prove its case as to why the accused should be so punished. This must especially be so when the punishment sought to be visited on

$23 \quad$ Ibid. 
the accused is the sentence of death. ${ }^{24}$

Justice Choo eventually held that on the basis of the evidence presented at the trial that led to the accused's conviction, the accused was no more than a courier. ${ }^{25}$ In the analysis that follows, three issues will be analysed: first, whether an accused's privilege against self-incrimination and right to presumption of innocence is infringed upon, even if unintended, by the new MDA provisions; secondly, whether the prosecutor is the best party to certify substantive assistance; and thirdly, whether sentencing guidelines would be desirable in this context.

\section{ANALYSIS OF CHUM TAT SUAN (HIGH COURT)}

\section{Privilege against self-incrimination and right to presumption of innocence}

Without being explicit in his judgment, Justice Choo must have been referring mainly to the privilege against self-incrimination and concomitantly, the right to the presumption of innocence. ${ }^{26}$ In his analysis, an accused drug courier can probably avail himself of section 33B of the MDA only if he had in some way confessed to liability before or during the trial. Otherwise, how else can he satisfy the first requirement of being just a courier in the drug syndicate? One need only consider that the usual defences ${ }^{27}$ raised by persons accused of drug trafficking would be to either deny knowledge of the existence of the drugs that are found on them or their belongings, or to deny knowledge of the contents of what they were told to traffic. These were the defences raised in Chum Tat Suan (High Court); this also explains

\footnotetext{
$24 \quad$ Ibid, 6.

25 Ibid, 7.

26 On the connection between the two, see Michael Menlowe, "Bentham, SelfIncrimination and the Law of Evidence," Law Quarterly Review 104(2) (1998): 303306; Andrew Ashworth, "Four Threats to the Presumption of Innocence," International Journal of Evidence \& Proof Vol.10, No.4 (2006): 255-256.

$27 \quad$ Public Prosecutor v Muhammad Farid bin Mohd Yusop [2014] SGHC 125. In this case, which involved the invocation of an unusual defence, the accused was found trafficking almost 400 grams of methamphetamine, an offence punishable by death. However, he succeeded in arguing that though he knew what he was carrying, his arrangement with his superior was that per previous arrangements, he would only traffic less than 250 grams, an amount that would not trigger the death penalty. $\mathrm{He}$ succeeded in his defence and the charge was amended accordingly.
} 
why the aforementioned presumptions in section 18 of the MDA exist. It is also possible for an accused to remain silent, but under section 261 of the $\mathrm{CPC},{ }^{28}$ if he raises a defence at trial that was not brought up when he was charged, adverse inferences may be drawn with regards to is guilt. ${ }^{29}$ There is only disadvantage to be gained if one keeps silent.

With all of the above in mind, if an accused drug courier wants to maximise his chances of escaping the gallows, he essentially has two options, both of which is wrought with some serious difficulty. On the one hand, if he is caught with a huge quantity of drugs and a conviction upon the likely charge may result in the death penalty, short of him having truly plausible defences against the statutory presumptions against him, he will probably want to admit that he is part of a drug syndicate before he is convicted and hope he is found to have rendered substantive assistance to the CNB so that section 33B of the MDA can be successfully invoked. On the other hand, if he is unsure that the likely charge may result in the death penalty, he may try to strike some kind of bargain with the prosecution beforehand that the quantity of drugs he is charged with trafficking does not trigger the death penalty - but this presupposes this can even be done, as current prosecutorial practices do not seem to allow such bargains to be made for drug trafficking cases..$^{30}$ At any rate, for both options, he is required to plead guilty at some point (but he would want to do so sooner rather than

$28 \quad$ See also CPC, section 22; Kwek Seow Hock v Public Prosecutor [2011] 3 SLR $157,[18]-[19]$.

29 The adverse inferences can also be used to determine whether to commit the accused for trial or whether there is a case to answer. However, they cannot be used to bolster an otherwise evidentially weak case: Took Leng How v Public Prosecutor [2006] 2 SLR(R) 70, [43]. A fortiori, adverse inferences per se also cannot be used to secure a conviction. See also CPC, section 23(1), which has a template warning to be read to the accused when his cautioned statement is being recorded: "Do you want to say anything about the charge that was just read to you? If you keep quiet now about any fact or matter in your defence and you reveal this fact or matter in your defence only at your trial, the judge may be less likely to believe you. This may have a bad effect on your case in court. Therefore it may be better for you to mention such fact or matter now. If you wish to do so, what you say will be written down, read back to you for any mistakes to be corrected and then signed by you." It should be noted that there is also another provision in the CPC that address adverse inferences; section 230(1) states that if an accused elects not to give evidence in court after the prosecution has made out a case, adverse inferences may be drawn as regards his guilt.

30 At least in relation to the MDA context. For other crimes, though not formalised in legislation, de facto plea bargains are often struck in pre-trial proceedings such as the Criminal Case Resolution. To be clear, the weight of pleas in Singapore is not as strong in jurisdictions such as the US, but nor are they devoid of some weight. 
later), while the prosecution holds all of the cards. Are there certain compelling features of the offence of drug trafficking that justify this asymmetry?

A Member of Parliament had raised this concern when the 2012 amendments to the MDA were being debated in Parliament. $\mathrm{He}$ questioned the fairness of the amendment when the accused drug couriers had to "be pressurised into incriminating themselves" in the calculated hope of avoiding the death penalty. ${ }^{31}$ In response, the Minister for Law said quite candidly: "if the accused knows something, and has to decide between trying to run a false defence that he knows nothing, and telling the truth and assisting the CNB - I do not think Members will argue against giving him an incentive to tell the truth, to help us, and to help himself." 32 This response, it may be said, is generally consonant with Singapore's longstanding subscription to the "crime control" model of criminal justice, which prioritises successful convictions over procedural rights in contradistinction to the "due process" model. ${ }^{33}$ It can also be said to be consistent with the criminal justice philosophy espoused by the courts over the years. ${ }^{34}$ For instance, the Court of Appeal has ruled that the right to silence

\footnotetext{
31 Second Reading of Misuse of Drugs (Amendment) Bill, Singapore Parliament Reports, 12 November 2012 (Eugene Tan).

32 Second Reading of Misuse of Drugs (Amendment) Bill, Singapore Parliament Reports, 14 November 2012 (Kasiviswanathan Shanmugam). In a speech in 2014, the Minister said that Singapore's “criminal justice system is anchored on four fundamental principles: our laws and the criminal process must protect society and uphold law and order ... due process and the rule of law must be observed, and sentences must be commensurate with the culpability of the offender and the seriousness of the offence ... our law enforcement agencies must be empowered to discharge their duties. And law enforcement should not be seen as a 'catch me if you can', or jumping through a series of technical hurdles ... where possible, offenders must be given the opportunity to be rehabilitated and reintegrated into society. We run one of the world's best programmes and that aspect hasn't received much attention": Ministry of Home Affairs (Singapore), "Keynote Address by Law Minister K Shanmugam at NUS-SMU Criminal Justice Conference", accessed December 1, 2014 https:/www.mlaw.gov.sg/content/minlaw/ en/news/speeches/minister-keynote-nus-smu-criminal-justice-conference.html.

33 See generally Chan Sek Keong, "The Criminal Process - The Singapore Model," Singapore Law Review 17 (1996): 433; Melanie Chng, "Modernising the Criminal Justice Framework: The Criminal Procedure Code 2010," Singapore Academy of Law Journal, Vol.23 No.1 (2010): 23. In the latter article, the author essentially makes the argument that crime control and the seemingly antithetical ideal of due process are not always conflicting with each other on opposite ends of the scale.

34 For an opposing view (and more modern survey of the jurisprudence), see Chen, "The Limits on Prosecutorial Discretion in Singapore," 15-18.
} 
(which overarches the privilege against self-incrimination) ${ }^{35}$ is neither a rule of natural justice nor a constitutional right, ${ }^{36}$ while the High Court has ruled that the right to silence is an impediment to an accused establishing whatever defence he has in a timely manner. ${ }^{37}$

In perspective, however, the right to silence has largely been modified or abrogated in other jurisdictions as well. A commentator describes the right as only being "theoretically intact" in England..$^{38}$ Be that as it may, the fact that an accused drug courier now has an additional disincentive to remain silent is, at the very least, another step away from his basic right to a presumption of innocence. ${ }^{39}$ Moreover, it cannot be ignored that jurisdictions that have abolished or come close to abolishing the right to silence do not have laws carrying the death penalty. ${ }^{40}$ Therefore, in the context of drug trafficking offences, there is a serious need to reflect upon the implications when the presumption of innocence is lessened. To what extent can communitarian interests, manifested in parliamentary will, be used to advance the ideals of crime control where it is literally a matter of life and death?

\footnotetext{
35 Adrian Keane and Paul McKeown, The Modern Law of Evidence (Oxford University Press: 2012), 409.

36 Public Prosecutor v Mazlan bin Maidun [1992] 3 SLR(R) 968, [15]-[19]. See also Ong Ah Chuan v Public Prosecutor [1979-1980] SLR(R) 710, [26]-[29]. On the importance of having a constitutional basis to protect an accused's rights, see Johannes Chan, "Constitutional Protection of the Right to be Presumed Innocent and the Right against Self-Incrimination," Singapore Academy of Law Journal 25(2) (2013): 679.

37 Yap Giau Beng Terence v Public Prosecutor [1998] 2 SLR(R) 855, [38].

38 Keane and McKeown, The Modern Law of Evidence, 595.

39 "Escaping the Gallows - Drug Mules, Death Penalties and Discretion," Innocence Project Singapore, accessed December 1, 2014. http://sginnocenceproject. com/2013/12/26/escaping-the-gallows-drug-mules-death-penalties-and-discretion/:"It is the information that a drug courier possesses rather than his culpability that exonerates him. This is ... a policy that can lead to unfair judicial outcomes. A drug courier who willingly volunteers to smuggle drugs into Singapore would be spared the death penalty if he has the information which can substantially assist the CNB. Conversely, a drug courier who was forced to smuggle drugs, and thus of lesser culpability, would not be spared from the gallows if he possesses no information that lends substantive assistance ... the requirement of substantial assistance goes little way towards proportionality and nuance ... it is expressly skewed in favour of deterrence, arguably at the expense of fairer sentencing." 40 Amnesty International claims that more than two-thirds of the countries in the world have abolished the death penalty in law or practice: Amnesty International, "Abolitionist and Retentionist Countries," accessed December 1,2014, http://www. amnesty.org/en/death-penalty/abolitionist-and-retentionist-countries.
} 


\section{Prosecutor's role in the certification of substantive assistance}

Aside from the above, there is also the matter of extending prosecutorial discretion that was not directly addressed by Justice Choo in his judgment. Quite apart from the problem of having the prosecution certify substantive assistance only after the conviction, there is the prior question of whether it should even be the prosecution that does this certification. ${ }^{41}$ While it is true that a sub-section in section 33B of the MDA allows the certification decision to be challenged on the grounds of bad faith or malice, recent case law (albeit in the constitutional law context) has confirmed that any challenge of prosecutorial discretion involves a few hurdles. ${ }^{42}$

First, there is always a strong presumption that the prosecution has exercised prosecutorial discretion in accordance with the law, given the high office the Attorney-General who assumes as a constitutional equal to the judiciary. Secondly, the burden is on the accused to adduce (prima facie) evidence of any improper exercise of prosecutorial discretion. Thirdly, even if the prosecution had exercised discretion improperly, the court can only make a declaration to that effect, but it has no power to do anything else, such as ordering a retrial or granting an acquittal. ${ }^{43}$ In this regard, there is no precedent in which prosecutorial discretion has successfully been challenged, and section 33B of the MDA is also silent as to the consequence of successfully challenging the certification decision.

Not only that, even if one decides to challenge the certification, this only protracts legal proceedings, which is often only to the detriment of

\footnotetext{
41 A presupposition here is that the certification issue only arises when a prosecution is brought - in other words, the prosecution cannot promise substantive assistance before the prosecution as some kind of plea bargain. This has to be the case or the purpose of introducing section 33B of the MDA would be completely defeated, not to mention an arrogation of the court's (legal) function to determine whether the accused is a courier.

42 See Ramalingam Ravinthran v Attorney-General [2012] 2 SLR 49, [24]-[45]; Yong Vui Kong v Public Prosecutor [2012] 2 SLR 872, [18]-[39]; Quek Hock Lye v Public Prosecutor [2012] 2 SLR 1012, [22]-[29].

43 Interestingly, however, the High Court and Court of Appeal have in previous cases exercised their judicial powers to liberate an accused when the circumstances are extreme: see for instance Yunani bin Abdul Hamid v Public Prosecutor [2008] 3 SLR(R) 383, [63]-[68]; AOF v Public Prosecutor [2012] 3 SLR 34, [306]-[315]. For a related and brief discourse on a court's inherent powers, see Chen Siyuan, "Is the Invocation of Inherent Jurisdiction the same as the Exercise of Inherent Powers," International Journal of Evidence \& Proof 17(4) (2013): 367.
} 
the accused, especially one on death row. ${ }^{44}$ Thus, in light of the sheer number of procedural hurdles and possible irreparable prejudice to the accused, some may take the view that it should be the court, and not the prosecutor that should decide if the courier had indeed rendered substantive assistance to the CNB. Alternatively, the threshold for certification should be lowered - for instance, to that of good faith cooperation. ${ }^{45}$ However, the Minister for Law rejected both possibilities during the parliamentary debates.

With respect to the former suggestion, he said that this was a matter relating to "operational information", which the prosecution has a better understanding of, and also has a duty of confidence not to disclose. ${ }^{46}$ With respect to the latter suggestion, he said it was not a realistic option as couriers may be "primed" by sophisticated syndicates with stories so as to appear to cooperate. ${ }^{47}$ While both responses by the Minister are not inherently unreasonable (but nor are they eminently unassailable as a matter of law or logic), it would seem then that ultimately, the Singapore government remains committed as ever (and democratically mandated) in its relentless war on illegal drugs and sees no need to recalibrate the state-versus-individual dichotomy for criminal

$44 \quad$ It should be noted that it is also possible to seek a presidential pardon under the Constitution of the Republic of Singapore (Revised Edition 1985, 1999 Reprint), article 22P but successful cases have been extremely rare. In this regard, see Yong Vui Kong v Attorney-General [2011] 2 SLR 1189.

45 See also Second Reading of Misuse of Drugs (Amendment) Bill (Edwin Tong): "By definition, an accused trafficker who satisfies the criteria in [section 33B] is likely to be a relatively low level transporter or assistant. That person is not likely to be in a position to give any substantive assistance especially if that assistance is to lead to some tangible disruption outcome ... I wonder whether the threshold is not set too high. Such a requirement would likely disadvantage the offender who was sitting at the lower end of the hierarchy with little or no information on the senior members of the inner workings of the syndicate ... It is possible that the assistance rendered or the information provided by the offender may either not be immediately or be fully appreciated. It is entirely possible that such information or assistance provided by the offender could be useless on its own but when put together with other pieces of information, obtained from other sources at other times, the fuller picture could well be very useful, and this may take several months or even years."

46 Second Reading of Misuse of Drugs (Amendment) Bill (Kasiviswanathan Shanmugam). The Minister also added that, on the prior question of whether it should be the courts or prosecution that frames the charge, it should be the prosecution as its assessment will be based on intelligence not within the knowledge of the court; it is better placed to take note of broad public policy considerations; and it is often the case that an accused is willing to plead guilty, but will not do so if the charge carries the possibility of capital punishment, even if it is discretionary.

$47 \quad$ Ibid. 
proceedings. The Minister for Law confirmed this as well during the debates by reminding the House in rather stark terms that:

Let us be clear. [Couriers traffic]for money. They know what they are doing is wrong. They hide the drugs in secret compartments, all sorts of places, and try and traffic through our check points. 15 grams is not little. It is 2,200 straws - you can feed the addiction of 300 abusers for a week ... The issue is not what we can do to help couriers avoid capital punishment. It is about what we can do to enhance the effectiveness of the [MDA] in a non-capricious and fair way without affecting our underlying fight against drugs. ${ }^{48}$

Not long after Chum Tat Suan (High Court) was decided, a judicial review application ${ }^{49}$ was filed regarding another section 33B case. In Muhammad Ridzuan bin Mohd Ali v Attorney-General, ${ }^{50}$ the accused sought a declaration that the prosecution had acted unconstitutionally and also in bad faith in not granting a certificate of substantive assistance under section 33B. Specifically, he argued that since his confederate in the very same drug trafficking enterprise was granted a certificate of substantive assistance based on information similar to what he had given to the $\mathrm{CNB}$, there was unequal treatment in the constitutional sense; moreover, in light of the observations in Chum Tat Suan (High Court), the accused is always in a dilemma as to whether or not to give information to CNB or to deny liability. In any event, the prosecution had not conducted a proper and formal investigation in deciding whether substantive assistance had been rendered. ${ }^{51}$

As a starting point, the High Court essentially reiterated the now-

48 Ibid. See also Second Reading of Misuse of Drugs (Amendment) Bill (Teo Chee Hean): "The policy intent of this substantive cooperation amendment to our mandatory death penalty regime is to maintain a tight regime - while giving ourselves an additional avenue to help us in our fight against drugs, and not to undermine it." In fairness, the government did not redefine existing offences in the MDA either to make it easier to secure convictions, a fear that is often expressed by human rights advocates when discretion is injected into sentencing.

49 Jeyaretnam Kenneth Andrew v Attorney-General [2013] 1 SLR 619, [5]. Under Singapore law, three conditions must be fulfilled before leave for judicial review is granted. First, the subject matter must be susceptible to judicial review; secondly, the applicant must have sufficient interest or locus standi in the subject matter; and thirdly, the material before the court must disclose an arguable case or prima facie case of reasonable suspicion in favour of granting the remedies sought. See also Vellama d/o Marie Muthu v Attorney-General [2013] 4 SLR 1, [53].

50 Muhammad Ridzuan bin Mohd Ali v Attorney-General [2014] SGHC 179.

51 Ibid, 20-23. 
established position that considerable deference should be accorded to the Attorney-General on prosecutorial decisions generally. ${ }^{52}$ With specific regard to the facts of the case, the court dismissed the argument that the accused would, as a matter of course and without actual proof, be in a better position than his confederate to assist the CNB only because he claimed to be ranked higher in the drug syndicate hierarchy. ${ }^{53}$ The court also noted that whether an accused has rendered substantive assistance "is largely a value judgment which necessarily entails a certain degree of subjectivity [and] the court should be careful not to substitute its own judgment for the [prosecution's] judgment." 54

Further, the court said that while the prosecution would consider factors such as the upstream and downstream effects of any information provided as well as its veracity when counterchecked against other intelligence sources, these are all extra-legal considerations best assessed by the prosecution. If the prosecution had to justify every certification decision in court every time allegations are made by accused persons, the operational effectiveness of the CNB will be hampered. ${ }^{55}$

Finally, as regards to the allegation about being deprived of ample opportunity to assist the CNB, the court held that no bad faith had arisen. It said that bad faith, in this context, is limited to the extraneous exercises of power, preconceived biases against the accused, or wholly arbitrary decisions. ${ }^{56}$ Not only had the accused failed to make out a prima facie case, the MDA "does not impose any legal duty on the part of the [prosecution] or the law enforcement agencies to expressly invite the accused to provide information [to the CNB]" and it is "in the accused's best interests to provide information as early as possible during the course of the investigations. ${ }^{" 57}$ All in all, any challenge of prosecutorial discretion by an accused - whether as regards prosecution

\footnotetext{
$52 \quad$ Ibid, 41, 44, 72.

$53 \quad$ Ibid, 47-48.

54 Ibid, 50.

55 Ibid, 50-51. This line of reasoning echoes the justifications used in national security matters, especially those involving indefinite detention.

$56 \quad$ Ibid, 57-61.

57 Ibid, 62-69. For completeness, it should be mentioned that this decision was preceded by another High Court decision regarding a similar challenge in Cheong Chun Yin v Attorney-General [2014] 3 SLR 1141. There, the accused had alleged that the leads regarding senior members of his drug syndicate that he had provided to CNB were not pursued and accordingly, the prosecutor's decision not to award a certificate of substantive assistance could be quashed on the basis of the commission of a jurisdictional error of law.
} 
generally ${ }^{58}$ or the certification decision in the specific context of section 33B of the MDA - will very unlikely result in success, not just from an evidential point of view but also in terms of the court's unwillingness to interfere with what it considers to be a proper separation of powers, if not legitimate executive supremacy. ${ }^{59}$

\section{Whether to sentence to death after the preconditions of section 33B are met}

Finally, perhaps the most crucial matter that was not considered by Justice Choo in Chum Tat Suan (High Court) was whether the accused should nevertheless be sentenced to death even though he was found to be a courier. This is through no fault of the court of course, as the

However, the court held that how the $\mathrm{CNB}$ and prosecution conduct its investigations in each case for the purposes of certification was simply not within the purview of the courts under the statutory scheme in section 33B of the MDA, and common law grounds of judicial review did not displace that. It should also be noted that in late-2014, new evidence emerged that gave the accused a chance at re-sentencing, so proceedings have not been concluded yet. While this development did raise the question of whether exonerating information that emerges after a drug courier has been hanged will dent public confidence in the new discretionary regime, this has more to do with the negative consequences of the death penalty generally rather than the new regime itself. This of course presupposes good faith on the part of the authorities.

58 Gary Chan, "Prosecutorial Discretion and the Legal Limits in Singapore," Singapore Academy of Law Journal 25(1) (2013): 15.

59 This may, of course, be a matter of characterisation. As stated by the Court of Appeal in Lim Meng Suang v Attorney-General [2014] SGCA 53, [6]-[7], the court "must disregard extra-legal considerations that are uniquely within the purview of the legislature ... where the court does indeed have regard to extra-legal considerations, this must (in the nature of things) be by way of a very limited brief premised only on what is absolutely necessary to enable the court to apply the relevant legal principles ... Drawing such a line in the legal sand is imperative. If this is not done, the court will necessarily be sucked into and thereby descend into the political arena, which would in turn undermine (or even destroy) the very role which constitutes the raison d'être for the court's existence in the first place - namely, to furnish an independent, neutral and objective forum for deciding, on the basis of objective legal rules and principles, (inter alia) what rights parties have in a given situation" (emphasis in original). The court added (at [189]): "the court can only consider legal (as opposed to extra-legal) arguments. This ensures that it will not become a "mini legislature". The court cannotand must not - assume legislative functions which are necessarily beyond its limit. To do so would be to efface the very separation of powers which confers upon the court its legitimacy in the first place. If the court were to assume legislative functions, it would no longer be able to sit to assess the legality of statutes from an objective perspective. Worse still, it would necessarily be involved in expressing views on extra-legal issues which would ... be ... subjective in nature" (emphasis in original)". 
legally subsequent questions of whether substantive assistance had been rendered to the CNB and whether the death penalty was appropriate in the circumstances were precluded from even being answered as the prosecution, had taken out a Criminal Reference to the Court of Appeal, seeking the apex court's guidance on the observations about the evidential difficulties of the section 33B preconditions made by Justice Choo. Be that as it may, it may be helpful to parenthetically understand the contours of the dilemma of whether to sentence an accused to death even after he has satisfied the preconditions in section 33B of the MDA before we consider the Court of Appeal's observations in the Criminal Reference (since, by definition, the Criminal Reference does not answer the question of sentencing and the Court of Appeal would have to remit the matter back to the High Court for the sentence to be passed first, it is apposite to consider this issue in this section).

First of all, if one peruses the section again one notices that section 33B is completely silent as to what factors, considerations, or circumstances should be taken as mitigating or aggravating factors when deciding which is more appropriate, the death sentence or life imprisonment and caning is preferable. ${ }^{60}$ Whether or not some sort of sentencing parameters should have been codified was actually raised and debated in Parliament, but it was ultimately decided that it should be the courts, and not the legislature, that should develop the principles. In other words, section 33B was deliberately left bare regarding the issue of sentencing considerations. The Minister for Law explained his position in the following terms:

While the courts will of course exercise any discretion in a principled and consistent manner, their view is that it is best that the legislature define in the clearest possible terms when the ultimate punishment is justified. That is the responsibility of the legislature, which is elected by the people ... How would we craft the statute to give more discretion to the courts ... Can we conceive of a discretionary

$60 \quad$ However, in Public Prosecutor v Purushothaman a/l Subramaniam [2014] SGHC 231 , the court held that under section 33B, life imprisonment is the only alternative custodial sentence to the death penalty; the only range applicable is the number of strokes of the cane. In relation to that, the court held that relevant factors would include the age of the offender, his motivation for trafficking, whether he was a repeat offender, whether there was cooperation with the authorities, and whether there were aggravating factors. The parliamentary debates do not yield a clear answer either. Section 33B of the MDA may also be contrasted with section 304 of the Penal Code concerning the discretionary death penalty for certain culpable homicide offences, in which the latter is much clearer in stating life imprisonment as the only possible sentence. 
sentencing approach which maintains the deterrent value of the death penalty across the whole spectrum of drug trafficking activities? With the best of intentions, it will be difficult - I think it is impossible. That is the view which we came to after discussing and considering the matter carefully, with the agencies, with the various AttorneysGeneral, and with the courts. Consider what factors you will set out for exercise of discretion: would you say age, youth? Would you say young mothers? Would you say impecuniosity? Would you say, see if the trafficker was baited with love? Or would you look at other family circumstances? You set out the criteria, whatever they are, and the drug lords will send you any number who will satisfy those criteria, who will perfectly fit the profile. This is because you are looking at background factors; the circumstances of the crime become less important ... You go down this route - in effect you might have a de facto abolition of the death penalty. ${ }^{61}$

Thus, Parliament's main motivation in refusing to state the guidelines was to preserve the deterrent effect of the MDA. On a separate line of thinking, it may also be said that leaving the matter unlegislated is a (long-awaited) triumph for judicial sovereignty and the separation of powers, as sentencing should always be within the domain of the courts. ${ }^{62}$ However, it ought to be borne in mind that:

Just as rules may cause arbitrariness in that legislative classifications adopted to formulate rules are inevitably arbitrary to some degree, a regime of discretion is also subject to criticism in that the exercise of discretion may well produce arbitrariness as well. One judge may

${ }^{61}$ Second Reading of Misuse of Drugs (Amendment) Bill (Kasiviswanathan Shanmugam). One also needs to understand the nature of law reform in Singapore. In recent years, the Ministry of Law has taken a more proactive role in making changes to or initiating new legislation. Stakeholders - other governmental agencies, lawyers, and academics - are consulted, and sometimes a report is generated before the bill is debated in Parliament. So one would have thought that scaling back on the mandatory death penalty would have induced a lot of debate in Parliament, but this was not the case. When the discretionary death penalty was introduced for certain types of murder offences for instance, only five (or around 5\% of the total number of Members of Parliament) had anything to say about it: Second Reading of Penal Code (Amendment) Bill, Singapore Parliament Reports, 14 November 2012.

62 Mohan and Chia, "The Death Penalty and the Desirability of Judicial Discretion". See also Mohammad Faizal bin Sabtu v Public Prosecutor [2012] 4 SLR 947, [43] [45], where the Court of Appeal held that the power to enact offences and to prescribe the corresponding punishments was a legislative power and not a judicial one; the duty of the courts is to inflict the legislatively prescribed punishments, exercising such discretion as might have been given to them by the legislature to select the punishments which they think appropriate. 
give rather more weight a mitigating factor than another, resulting in the death penalty for one offender and not for another, although both offenders are similarly situated. And if the courts try to prevent this kind of arbitrariness, they will have to fashion "guidelines" which, if enforced consistently, will morph into de facto rules. ${ }^{63}$

It seems, then, that the two most plausible outcomes emerging from the lack of sentencing guidance in section 33B are that first, the courts themselves would have to develop some kind of clear guidelines so as to achieve an acceptable level of sentencing consistency, perhaps similar to the way the common law incrementally creates principles concerning mitigating and aggravating factors. This is imperative as "the presence of inconsistency in sentencing diminishes the idea of justice being equal to all in a legal system ... leads to public cynicism ... and eventually, to the loss of public confidence in the administration of justice." ${ }^{64}$ In this regard, the Singapore courts have recently emphasised the importance of sentencing benchmarks in certain types of crimes, presumably in furtherance of this ideal of consistency (and concomitantly clear) ${ }^{65}$ - which is surely a tenet of any conception of the rule of law, though it must be recognised that the perennial and endemic

63 Hor, "The Death Penalty in Singapore and International Law," 112. For a commentary on the suggested sentencing guidelines certain types of murder offences (of which, as mentioned, the discretionary death penalty now also applies, and of which, the corresponding statute is also silent on sentencing considerations), see Mohan and Chia, "The Death Penalty and the Desirability of Judicial Discretion". For a commentary on how the legislative decision not to regulate judicial prerogatives (such as inherent powers), albeit again in a separate context, this time in that of evidence law, see Chen Siyuan, "The 2012 Amendments to Singapore's Evidence Act: More Questions than Answers as Regards Expert Opinion Evidence?" Statute Law Review 34(3) (2013): 262; Chen Siyuan, "The Future of the Similar Rule in an Indian Evidence Act Jurisdiction: Singapore," National University of Juridical Sciences Law Review 6(3) (2013): 361.

64 Public Prosecutor v UI [2008] 4 SLR(R) 500, [19].

65 See for instance Edwin s/o Suse Nathan v Public Prosecutor [2013] 4 SLR 1139 (drink driving) and Public Prosecutor v Hue An Li [2014] SGHC 171 (causing death by a negligent act). In a speech at the 2014 Sentencing Conference (Singapore Academy of Law), Chief Justice of Singapore, Sundaresh Menon, outlined the following pillars of sentencing: first, identify the purpose of the penal legislation; second, explore the full spectrum of prescribed options and identify the one that is most proportionate on the facts; third, like cases should be treated alike; fourth, consider the characteristics of the offender and circumstances of the offence; fifth, consider alternative sentences where applicable; and fifth, judges should give proper reasons in their decisions (facts, mitigating factors, and aggravating factors) so that their exercise of discretion is justified. 
tension between the principles of consistency and individualised justice will never go away. ${ }^{66}$

But an equally plausible outcome that may well materialise at the same time is that there may be a de facto abolition of the death penalty for drug couriers (assuming they also satisfy the substantive assistance requirement), if the death penalty is going to end up being rarely invoked. Even the Minister for Law noted in the parliamentary debates that when there are sentencing options to choose from, judges tend not to go for the maximum, unless there are exceptional circumstances, such as when the offence was committed in a particularly egregious manner. ${ }^{67}$ Indeed, if the judge actually seeks submissions on sentencing, it is difficult to see how the prosecution can still recommend the death penalty if the prosecution had already confirmed and certified substantive assistance. ${ }^{68}$ Fact-sensitive justice in the context of avoidable capital punishment is thus likely to take on a different meaning. Combining the two outcomes, it seems a matter of time before the death penalty is phased out, at least for drug couriers on account of their presumptive lower moral culpability. Yet this is precisely what Parliament did not intend as a natural consequence. ${ }^{69}$

There is of course a third possible outcome: that a trend emerges whereby the prosecution withholds from charging the accused with an offence (by increasing or decreasing the quantity of drugs that the accused allegedly trafficked) that may lead to the death penalty to begin with, if it seems that the accused did not have that high a level of moral culpability. ${ }^{70}$ However, even if a downward trend of capital

Chief Justice of Western Australia Wayne Martin, featuring as guest speaker at the same conference, suggested that the art of sentencing involves identifying what is reasonably proportionate and balancing contradictory and incommensurable objectives.

${ }_{66}$ In the same way that the debate as to whether sentencing is an art or science will never go away.

${ }^{67}$ Second Reading of Misuse of Drugs (Amendment) Bill (Kasiviswanathan Shanmugam). See also Sia Ah Kew v Public Prosecutor [1974-1976] SLR(R) 54, [5].

68 If so, this is yet another cession of power from the judiciary to the executive, in the sense that the prosecution is in effect deciding whether a death penalty is warranted at two stages: first, when the charge is framed; and secondly, when deciding on whether substantive assistance has been provided.

69 The point about a mandatory purposive interpretation of all statutory provisions in Singapore has already been made earlier. Another potential conflict is that generally, the importance of retribution and deterrence as sentencing principles has been on the wane for some time already.

70 Peggy Pao-Keerthi, "Looking Beyond Prospective Guidance: Sentencing Discretion in Capital Drug Framework and Lessons from the US," Singapore Academy of Law Journal 26(2) (2014): 529-530. 
drug charges emerges, one will imagine this may change if there is evidence of an increasing number of drug abusers or the drug trafficking situation getting out of hand. ${ }^{71}$ But to return to the matter of judicial discretion, leaving it to the courts to develop sentencing considerations will inevitably mean that the jurisprudence will take some time to crystallise. ${ }^{72}$ The multiple downsides of developing sentencing guidelines incrementally via case law were also recognised by Judge of Appeal Justice Chao in the recent 2014 Sentencing Conference organised by the Singapore Academy of Law, and of particular note is that insofar as the adversarial system is preserved in the criminal justice system, the quality of jurisprudential guidelines will depend in no small part on the quality of the criminal defence bar.

One imagines too that Criminal References (and Criminal Motions by necessity) will continue to be filed as the Attorney-General's Chambers seek further clarifications on issues of law from the Court of Appeal as and when such a need arises. Certainly the Singapore courts appear to welcome this new dynamic in the criminal justice system. But all of this has important implications for the accused, who is forced to wait indefinitely to learn of his fate. Efficient as Singapore courts are (and they are already one of the fastest in the world), such waiting can still last for a number of years, especially if application is filed after application. Providing a set of factors - not fixed criteria - for consideration in the legislation would have helped prevent this, or at the very least, given some consistency and clarity from the outset. ${ }^{73}$

\footnotetext{
Although the courts have the power to amend charges, this is somehow not done that often in capital drug cases. It should also be noted that based on modern practices of the Attorney-General's Chambers, capital drug trafficking cases are internally reviewed on several levels before charging decisions are made. Presumably, the substantive certification process will also be subject to these multi-level internal reviews.

71 "Drug Situation Report 2013," Central Narcotics Bureau, accessed December 1, 2014 http://www.cnb.gov.sg/drugsituationreport/drugsituationreport2013.aspx. Although the court has the power to amend the charge at any time, it does not exercise this power consistently.

72 To be clear, there have thus far been a few cases that have re-sentenced accused persons pursuant to section $33 \mathrm{~B}$, but written grounds of decision have generally not been forthcoming: Pao, "Looking Beyond Prospective Guidance", 536-539. One exception is Abdul Haleem bin Abdul Karim, [58], which considered factors such as whether there were antecedents, the motivation behind committing the offence, and the exact role of the accused notwithstanding his characterisation as a courier.

73 For a differing account see Pao, "Looking Beyond Prospective Guidance", 520. There, the author surveyed the established jurisprudence in the US, noting that "weaknesses of death penalty sentencing statutes in the US - that they contain long lists of broad or vague aggravating factors; that catch-all phrases are used;
} 
In this regard, though the governing legislation and sentencing options are admittedly different from Singapore's, it is interesting to note that in England and Wales, the Sentencing Council has made a number of specific recommendations when the accused in a drug trafficking offence is a non-professional mule; for instance, if a mule was acting out of need and naivety rather than greed, this is likely to result in less severe punishment. ${ }^{74}$ The absence of statutory guidelines and a full-fledged sentencing council in Singapore ${ }^{75}$ may thus prompt the courts to look at the practices of other jurisdictions, but this may be a challenge in so far as most of the developed jurisdictions no longer have the death penalty, discretionary or otherwise. It seems, the Singapore courts will be expected to give particularly clear and cogent reasons and principles in their sentencing decisions where section 33B of the MDA is concerned. That way, the Court of Appeal will also have a better picture as to whether the sentence imposed is appropriate if there is an appeal. ${ }^{76}$

and that little or no guidance is given to sentencers on how to weigh the various aggravating and mitigating factors - are not symptoms of incompetent drafters or poor doctrinal choices. Rather, they are indicative of the ineluctable trade-off between the need for consistency and the imperative of doing justice in the individual case." Accordingly, she rejects the notion of prospective guidance and instead advocates "the organic and incremental development of principles through the accumulation of cases ... However, in order to ensure the development of rational and holistic principles, the court's sentencing reasoning ... should be properly captured."

74 March 2011, "Drug Offences Guideline," Sentencing Council March 2011, accessed December 1,2014 http://sentencingcouncil.judiciary.gov.uk/docs/Drug Offences_Guideline_Professional_Consultation.pdf. The Sentencing Council is an independent, non-departmental public body of the Ministry of Justice and is responsible for developing sentencing guidelines and monitoring their use. Elsewhere, the legislature in New Zealand is involved in the development of the guidelines, while in the USA, guidelines are very detailed and cater to many different factual possibilities. Perhaps a little too innovatively, China has even experimented with computer-aided sentencing. This idea of computerised sentencing was not only alluded to by Justice Chan Seng Onn at the 2014 Sentencing Conference, but also recommended for adoption. 75 The Supreme Court does have a Sentencing Council and a sentencing database, but their scope is limited to consistency of sentencing in the State Courts for now. Recently introduced as well are specially convened, three-judge panels to hear complex appeals for criminal cases emanating from the State Courts - such appeals are usually heard by a single judge.

76 Tan Koon Swan v Public Prosecutor [1985-1986] SLR(R) 976, [3]-[9]. 


\section{CONCLUDING THOUGHTS}

Pulling all the threads together, the following four observations can be made:

(a) Although the 2012 amendments to the MDA may be motivated by a desire to recalibrate the appropriate culpability attached to drug couriers, it was clearly not meant to compromise in any way the effectiveness of the robust anti-drug regime in Singapore. This, in turn, informs any analysis of the amendments' implications as regards the rights of, and impacts on, the accused. It is important not to mistakenly think that the purpose of the amendments is to show greater compassion to lowly ranked members of drug syndicates, or that there is any diminution in the belief that the death penalty works as an effective deterrent against drug trafficking. If anything, it may be said that the purpose of the amendments is served by the prospect of couriers taking the bait to avoid mandatory death and "ratting" on higher-ups in the drug syndicate in return. In this connection, it should be borne in mind that in Singapore, the purposive approach dislodges all other canons of statutory interpretation.

(b) It is difficult to see how a drug courier can hope to successfully avail himself of section 33B of the MDA if he does not first confess to liability and pleads guilty to the drug trafficking charge. If he keeps quiet or changes tack only later on, this is unlikely to work in his favour and indeed may be held against him in a very real sense. The Singapore government seems to take the view that the derogation from his privilege against self-incrimination and the right to a presumption of innocence is the appropriate trade-off for a possible avoidance of mandatory death. This is

According to the Court of Criminal Appeal in that case, there are four established grounds as to when an appellate court can interfere with a sentencing decision: if the sentencing judge has made a wrong decision as to the proper factual basis for the sentence; there has been an error on the part of the sentencing judge in appreciating the material placed before him; the sentence was wrong in principle; or the sentenced imposed was manifestly excessive or inadequate. See also CPC, section 394: "Any judgment, sentence or order of a trial court may be reversed or set aside only where the appellate court is satisfied that it was wrong in law or against the weight of evidence or, in the case of a sentence, manifestly excessive or manifestly inadequate in all the circumstances of the case." 
consistent with the principal aim of the amendments and also the general tenor of the criminal justice system in Singapore. So long as the government retains the longstanding democratic mandate of the people, the prioritisation of crime control is legitimised parochially. One may, of course, maintain that if an accused is indeed innocent, his right to a presumption of innocence (whether manifested in the form of the privilege against self-incrimination or otherwise) is unaffected by the amendments from an evidential point of view. However, one also cannot rule out the possibility that an innocent accused may be induced to confess and avoid death rather than take the chance of being wrongfully convicted. This possibility may seem remote in a generally corrupt-free Singapore, but a criminal justice system should guard against all eventualities to whatever extent feasible.

(c) Both Parliament and the courts (at least thus far) have decided that the prosecution is in a far better position (than the court) to assess the question of whether substantive assistance has been provided to the CNB in disrupting drug trafficking activities within or outside Singapore, mainly on the basis that the assessment of such a question would involve the weighing of many extra-legal considerations that are (or should be) outside the purview of the courts. Further, although the MDA allows the certification decision to be challenged on the grounds of bad faith or malice, it seems almost impossible for any accused to prove this given the jurisprudential presumption of propriety afforded to the Attorney-General. The tilt in favour of executive supremacy, and acceptance of parliamentary legitimacy, is strongest here. However, as it were, a lot of power and responsibility is already given to the prosecution as regards the prosecutorial process generally. Perhaps the conundrum that arises from creating additional powers for the prosecution regarding the certification process may be resolved by having the prosecution (or even the court) amend the charge so that it no longer triggers the death penalty, but this will result in section 33B being a legislative amendment in vain. Another complication is that the range of punishments may differ depending on the type of drugs trafficked. ${ }^{77}$

MDA, Schedule 2. 
(d) Even if substantive assistance has been certified, there still remains the question of whether the death penalty should be meted out. Section 33B of the MDA is completely silent on this, and this was a deliberate move on the part of Parliament as the preference was for the courts to incrementally develop sentencing guidelines on their own terms. Again, this was meant to preserve the deterrent effect of the MDA more than anything else (as opposed to restoring judicial prerogative). However, without pre-existing guidelines, it is likely that the courts will reserve the death penalty only for the most egregious types of drug couriers, and the de facto abolition of the death penalty (for drug couriers at least) will accordingly eventuate, which is contrary to what Parliament intended. After all, it is unlikely that the prosecution will certify substantial assistance if circumstances suggest that the accused is far from an exploited vulnerable. Separately, without the benefit of relevant comparative experience, the only way in which the Singapore courts can achieve sentencing consistency and individualised justice in future section 33B cases is to give particularly clear and cogent reasons and principles in every decision that is rendered. This is not a task beyond the judiciary of course, but it will definitely mean that sentences take longer to pass and the jurisprudence takes longer to cohere. This always has a toll on people on death row.

The accused in Chum Tat Suan (High Court) is but one of many awaiting their fates, as it is believed that there are some 20-odd accused persons originally sentenced to death for drug trafficking who are eligible for re-sentencing by virtue of the MDA's transitional provisions. ${ }^{78}$ The Court of Appeal's impending observations in the Criminal Reference filed will certainly be examined closely in the months to come, and it is hoped that this article will provide an additional view

\footnotetext{
78 Pao, "Looking Beyond Prospective Guidance", 535; Ministry of Home Affairs (Singapore), "Statement by MHA in Response to Media Queries Regarding Capital Punishment", accessed December 1, 2014. http://www.mha.gov.sg/news_details. aspx?nid=MzIxMg\%3D\%3D-JKr4CnFh6eQ\%3D.. Interestingly, between 2010 and 2012, there were only two executions for drugs-related offences: Singapore Prison Service, "Greater Community Involvement Contributes to Lower Re-offending Rates", accessed December 1, 2014 http://www.prisons.gov.sg/content/dam/sps/publication latest $/ 2013 \% 20$ Singapore $\% 20$ Prison $\% 20$ Service $\% 20$ Annual $\% 20$ Statistics $\% 20$ Release.pdf.
} 
as to the possible issues that arise out of the amended MDA provisions. To the extent that there are also other jurisdictions with similar drug legislation and the mandatory death penalty, or that may have plans to introduce a discretionary death penalty regime, the Singapore experience may even be of comparative value. 
